\title{
The Geopolitical Implications of the New Developments on Global Energy Markets: The Major Energy Actors Case
}

\author{
Rafal Hryniewiecki • Alfonso Giordano
}

Published online: 8 May 2013

(C) The Author(s) 2013. This article is published with open access at Springerlink.com

\begin{abstract}
The article intends to identify and explain possible geopolitical implications for the main energy actors of the new developments on global energy markets and the effect on their foreign policy. To this end, a comparative analysis is provided, including Russia, United States, China and Qatar case studies. Authors examine the international activity of these states with special focus on the process of power shifts between them, their possible alliances and emerging interdependencies. The findings consist of a set of indications regarding direction and strength of geopolitical implications for each country (strong, moderate, negative and positive), foreign policy preferences (enhancement of energy security, maintaining its current position on the energy market or empowering of the state based on controlling supplies or transit of energy resources) and foreign policy strategy (expansive or conservative and offensive or defensive).
\end{abstract}

Keywords Global energy markets · Energy security · Foreign policy · Interdependencies

\section{How Independent is the Energy Sector: An Introduction}

The world energetic panorama has been associated with decision-making and political processes for past decades. The main reason for this is that the continuous

R. Hryniewiecki points out that the content of this article represents his personal views and not an official position of the Ministry of Foreign Affairs of the Republic of Poland.

R. Hryniewiecki $(\bowtie)$

The Embassy of Poland in Rome, Rome, Italy

e-mail: rafalhryniewiecki@hotmail.com

A. Giordano

Department of Political Science, LUISS University, Rome, Italy

e-mail: algiordano@luiss.it 
supply of hydrocarbons and energy security of the state have become essential components of national security, which in the previous years has been limited mainly to political and military issues. Despite the continuous efforts of progressive liberalization of energy resources trade in the world, political affairs still play a key role in global energy markets as evidenced by the recent events in the Arab Spring.

Changes on energy markets can also be a motor of significant political processes in international relations and drivers of globalization. Distribution of energy resources in the world brought to power some states (if states had a capacity of converting this strategic resources into the power ${ }^{1}$ ), created new interdependencies, but also resulted in several conflicts. Therefore, each state should take into account the importance of such strategic resources in their foreign policy, which should lead to a further protection of their energy interests in the international arena.

In recent years it is possible to observe the revolutionary changes on global energy markets, particularly with regard to gas, which, according to International Energy Agency (IEA 2011), should become the most important energy source. The revolution of shale gas, diffusion of $\mathrm{LNG}$, retreat from nuclear energy in some countries after the accident at the Fukushima Daiichi, the increasing policy focus on energy efficiency have potentially far-reaching consequences not only for markets and energy flows (e.g. further liberalization on gas market) but also for geopolitical balances. According to authors of this article, even if those changes lead to progressive liberalization of the energy market, they will not fairly de-politicize the energy sector. In the future, because of these developments, energy would not be used directly as a coercive (negative) political tool (e.g. interruption of supplies as political pressure). However, energy will remain an important factor in international relations (in particular the access to reserves, new transport routes).

It's important to emphasize that the existing studies mostly focus on issues regarding the effects of new developments on energy markets and climate. As a matter of fact, current literature broadly describes how economic processes can affect oil and gas market (Hryniewiecki and Boronska 2010), inducing to think that global energy markets can be considered as a variable that depends on several factors. Nevertheless, as assumed in this article, energy trends can be analysed as independent variables that may have geopolitical implications for specific political actors (dependent variable).

The authors will attempt to answer the question what will be the impact of new energy trends on states holding a major role on the energy markets, especially in the gas sector where are observed the most revolutionary changes. The article will provide a comparative analysis of Russia, United States, China and Qatar, examining in depth their activities and how the redistribution of power process among them is developing, looking in particularly at specific issues like empowering of state, possible allies, interdependencies, foreign policy preferences and strategies. As the analysis here presented is based on global energy framework elaborated on several previous reports, authors will only mention major trends to draw conclusions on the topic. Although the authors are fully aware of other implications associated with new phenomena provoked by energy trends (such as

\footnotetext{
${ }^{1}$ Nigeria is an example of a state which cannot convert its energy potential into the political power.
} 
water resources risk associated with energy production, new routes of transport) these elements will not be taken into exam as they would fairly extend the scope of the present research.

The article is organized in following way. The first part presents a theory and criteria for further analyses. The second part is devoted to the analysis of case studies predeceased by the general description of main trends on global energy markets. It should lead to forecasts of possible geopolitical implications.

\section{Theoretical Explanation of the International Energetic Arena}

In order to elucidate the impact of new energy trends on the selected countries this paper combines the rational and strategic choice approach (Lake and Powell 1999; Levy 1997) within the theoretical framework of realism (Carr 2001; Donnelly 2008).

Realism holds that countries are still key actor in shaping the international environment both as regards bilateral and multilateral relations (Carr 2001; Donnelly 2008). Although nowadays energy companies play an important role in energy international relations, states are still main actors as more than $70 \%$ of world oil reserves are owned by controlled states companies (Forbes 2012). In line with the rational choice approach, it is assumed that states act rationally in the pursuit of their self-interest, with the primary objective to maintain and ensure their own security and thus sovereignty and survival (Levy 1997). To this end, they will attempt to accumulate resources (i.e. energy resources), and create foreign policy to achieve their energy interests on the international scene. As the energy resources are not unlimited, countries have to compete (offensive realism) both to satisfy their fundamental need of energy security, and to expand their political influence (Mearsheimer 2001). This aggressive approach, however, leads to a situation where increasing one state's energy security can lead to an even greater instability as power opponent can build counterinstruments to protect its own interests. Consequently, energy security becomes a zero-sum game where only relative gains can be made (Quercia 2012). ${ }^{2}$ This article will attempt to identify the potential winners or losers of this game.

Realism also assumes that there are no universal principles to which states can guide their actions (Levy 1997). On the contrary, in line with the strategic choice approach (Frieden 1999), every country analyses and anticipates the actions of other states and adjusts its strategies accordingly. This entails necessity to monitor and analyse other actors' expected policies (e.g. country dependent on one gas importer will be eager to diversify its supplies). This, in turn, involves obtaining information regarding energy trends and forecasts on possible resources in some countries. In

\footnotetext{
${ }^{2}$ According to Quercia there are three major paradigms of energy policy strategies. First, the import dependent country strives to ensure itself a stable supplies. This fact mobilizes this state to explore new routes of import or to be more involved in exploration of its own resources. The oil and gas producer country, on the other hand, wishes to find a stable demand for its resources and also to expand the export possibilities (new pipelines, LNG). In the interest of a transit country (third strategy) is to become a hub. This position is helpful not only for enhancement of energy security but also for empowering of the state thanks to advantageous geopolitical position towards both consumers, as their security partly depends on this transit, and the producer countries which has to negotiate prices for transit of its resources to different states.
} 
this regard, only assumption about the potential existence of new strategic resources in oil and gas dependent country might fairly affect its geopolitical position vis a vis the current supplier.

Accepting the above arguments, several preferences of foreign policy for states acting on global energy markets can be identified. According to country geopolitical position and its energy potential, these preferences will be: enhancement of energy security, maintaining its current position on the energy market or empowering of the state based on controlling supplies or transit of energy resources. These preferences lead to certain foreign policy strategies. Some of them can be connected with the country's external behaviour. In this regard, we can differentiate between an expansive and conservative strategy. In the first case, the country will seek new partners in its non traditional zone or present an aggressive approach on international arena to achieve its preferences, e.g. energy security or growing political power. In the second case, the country is less interested in expanding its international presence for the purpose of energy needs. It will rather consider decreasing its involvement in certain regions to consolidate its current position. On the other hand, the authors will distinguish an offensive and defensive strategy. It will depend on the openness and readiness of state for developments on the energy market. The offensive strategy will characterize states who are the leaders and the launchers of major trends on the energy markets like shale gas, LNG or who are highly interested in those developments. These states will be generally supporting these trends and technological solutions on international arena. On the other hand, the defensive strategy will concern countries using different pressure mechanisms to slow down the new developments to protect its current interests.

\section{New Developments on Global Energy Markets}

According to current literature, several international institutions and energy companies reports new developments are occurring on energy markets (Statoil 2012; ExxonMobil 2012; WEO 2012). All of them assume that in recent years revolutionary changes on global energy markets raised with the establishment of a new world energetic panorama characterized by moves in global energy demand from the triangle US-Japan-EU to emerging Asia (especially China and India).

The International Energy Agency World Energy Outlook 2012 (WEO 2012), chosen as a point of reference for this analysis, indicates three pillars of movement of the current global energy system: revival of production of oil and gas in some states, nuclear retreat in others, signs of growing political attention in the field of energy efficiency. For the purpose of this article the authors focus mostly on the first pillar indicating liberalization of the oil and gas market (thanks to revival of production and diffusion of LNG technology) as their first independent variable. The other two pillars will be less explored as they are less connected with the core analysis; this is to say geopolitical implications. ${ }^{3}$ However, both pillars will be taken

\footnotetext{
${ }^{3}$ The energy efficiency regards mostly internal policy. "Nuclear diplomacy", on the other hand, was a domain and the priority of foreign policy of only one state-France.
} 


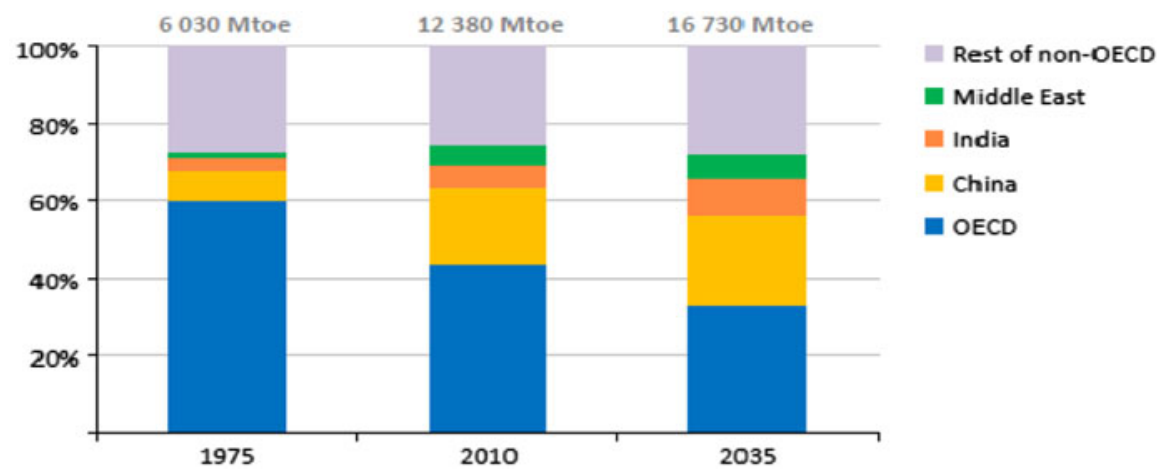

Fig. 1 Share of global energy demand to 2035. Source: WEO (2012)

into account in analysing the impact of the second independent variable - a shifting global energy demand which can have far-reaching consequences not only for energy markets but also for a map of geopolitical interests.

Revival of production of oil and gas associated with the revolution in unconventional resources, particularly shale gas and shale oil, results not only in a strong decrease of the price of these resources. It also changes the current map of geopolitical interdependences. Some countries, previously heavily energy dependent, can turn into producers in the near future. Others, with capacity of converting new resources into power, might even become an important regional player (Kaplan 2012).

Another key development is the diffusion of LNG, which facilitates energy flows and weakens oil linked long-term contracts (LTCs). LTCs, with its famous "take-orpay clause" have highly politicized energy relations based on the number of preferential agreements between producer countries and consumer countries.

As Figs. 1, 2 shows, the energy markets will probably not be fully globalized by 2035 but consumer countries will have more options to choose their supplier, which therefore will decrease dependence and weaken the possibility of using energy by its producers as political instrument. ${ }^{4}$

According to the WEO (2012) findings the changing outlook for energy production and use may redefine global and economic geopolitical balances. Policymakers will face critical choices in reconciling their objectives. For these reasons the authors will focus on such countries as Russia, United States, China, Qatar which are not only major energy player but also important political actors.

\section{The Geopolitical Implication for Major Energy Actors}

Russia has been a typical example of a country that gained political profits from its energetic resources (Giordano 2009). During the last 20 years Russian preference in

\footnotetext{
${ }^{4}$ According to J. Stern (The Oxford Institute for Energy Studies) LTCs in its old formula are no longer competitive. However, it is not expected to be over. It will rather become more flexible formula without take-or-pay clause and for shorter term (maximum 10, 8 years), Conference European Gas Challenges: demand and pricing, 26.11.2012, Rome.
} 


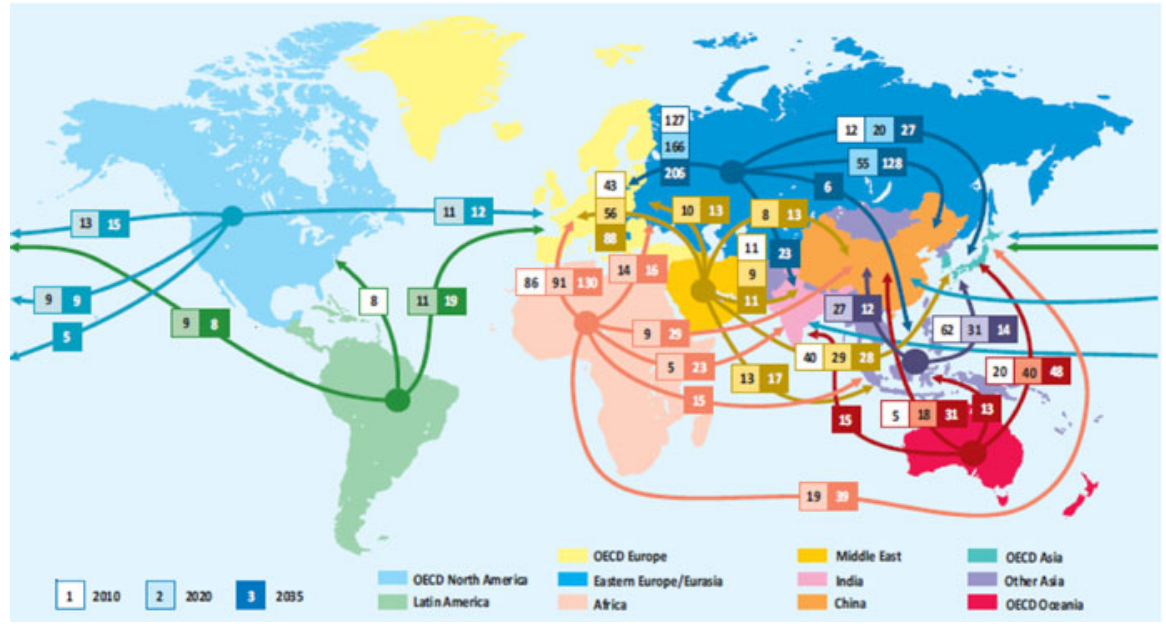

Fig. 2 The prediction of major global gas trade flows, 2035. Source: WEO (2012)

foreign policy was empowering of state based on controlling export and transit of energy resources to Europe (Kononczuk 2012). However, recent developments on the global energy markets will have probably strong and negative implications for Russia. Moscow should be concerned about the popularization of LNG and an increased supply of cheaper gas, which is the consequence of the shale gas revolution. Russia will struggle to sell energetic resources to Europe at high prices and with old LTCs because of the increasing competition. ${ }^{5}$ On the other hand, there are European potential shale gas reserves, especially in Poland and Ukraine, which could highly decrease Central-Eastern Europe strong dependency on Russian energy resources - an important power factor in Moscow's geopolitical position towards countries of this region and the EU.

Taking into account the above, Russian foreign policy preference will be maintaining its current position at the market as long as possible. Moscow intends to achieve it speeding gas-pipeline projects up in order to bind up countries which would participate in investments like the South Stream (Kardas and Paszyc 2012). Moreover, Kremlin's diplomacy obstructs implementation of the European Union's Third Energy Package by using its WTO new membership status. According to some experts, Russia may support a campaign against the shale gas in Europe. To this end, it uses very sophisticated instruments like negative media campaigns (e.g. Russia Today - a TV channel in English, frequently broadcasts very critical reportages about shale gas) or funding campaigns against fracking technology (Burgess 2012). Russia is opening to foreign investors (large contracts for the

\footnotetext{
5 According to Bellodi (Senior Vice President of Eni), progressive changes in the market indicate that a return to the model of indexing gas prices based oil-link formula is impossible. This model could be competitive to spot prices only if crude oil prices could fall to $70 \$$ per barrel. Thanks to LNG development consumers are gaining a stronger position. The example of this is a European Commission procedure against Gazprom. Conference: World Energy Outlook 2012 presentation, 14.12.2012, Rome.
} 
exploration of the Arctic signed by Rosnieft with ExxonMobil, Eni, and Statoil) aiming at filling the technological gap in and, hence, becoming more competitive.

Paradoxically, the developments in Russia, where generally the resources of hydrocarbon of both types: conventional and unconventional exist, ${ }^{6}$ will rather not have any bigger impact on the maintenance of Russia's geostrategic power. This power has not been so far based on a position of "the most competitive producer", but on the advantage of being a monopolist. Therefore, the most dangerous for Russia are almost inevitable external developments, which might bring the Russian monopoly on the gas market to an end. The foreign policy activities already mentioned above will probably only allow Russia to postpone it. In order to prevent its decline, Russia will rather pursue an expansive-defensive foreign policy both with regards to bilateral and multilateral fields (like WTO procedures against Third Energy Package implementation) to protect its current positions. Moscow, in view of the loss of its current supply monopoly, might try to gain control of new routes of energy transport (e.g. Russian Arctic aggressive policy, Blank 2011). It is rather unlikely that Kremlin would come back to the efforts of creating gas cartel because unconventional gas production occurs mainly in countries that are politically far away from Russia (US, Qatar, Australia). Nonetheless, it will be difficult for Russia to use the energy as a political instrument in a long term and Kremlin will have to get more involved in the development of more economically profitable but less politically influential oil sector companies (TNK-BP and Rosnieft fusion is probably a sign of this approach).

United States have been the biggest importer of the energy resources for last decades. Currently they import about $20 \%$ of their general energy demand. This fact has obviously influenced American foreign policy, where one of the main preferences has been concentration on reinforcing its energy security. As a consequence, a fundamental principle of American activities on international arena was to maintain its influence in the Middle East in order to protect current hydrocarbon supply to the US. Therefore, in past decades US deployed army forces in Saudi Arabia, Kuwait, and Qatar; besides, it was deeply involved in conflicts with Iraq in 1991 and 2003 (Fandy 1997).

However, the recent increase in the American production of unconventional oil and gas has shown that the role of North America in the world energy market is changing. According to WEO (2012) US will become the biggest world producer of oil by 2020 and net oil exporter by 2030. This fact will have probably a serious implications for American foreign policy preferences. When America meets the objective of energy self sufficiency the previous preference regarding enhancing energy security through protecting its strategic foreign suppliers will not be actual anymore. It means that in the future Washington may lose its interests in defending its position in the Middle East. This may evoke serious consequences for traditional American allies such as Israel or Saudi Arabia and Jordan where Washington supports the local monarchies. Washington may not be interested in keeping its

\footnotetext{
${ }^{6}$ Last reports suggest that in Russia could produce between 5-20 thousands of bcm of shale gas by 2025-2030. The Ministry of Energy has even recommended preparations for the potential development of the technology of the production from this source but Gazprom, which is a superpower in the conventional gas, still remains skeptical.
} 
soldiers in these countries, or at least could not be ready "to die for the undemocratic regimes" in case of protests similar to those that occurred in other countries during the Arab Spring (Ratner and Nerurkar 2011). ${ }^{7}$

American energy self-sufficiency in addition to other new developments on energy markets, may have also important implications for balances and interdependencies in the whole region. Dynamically growing oil production in Iraq will enhance slowly its political influence in the region (IEO 2012). The intervention in Iraq in 2003 gave hope for possible change of the negative regional constellation characterized by difficult relations between Saudi Arabia, Iraq and Iran. However, it is still not known whether new government in Baghdad carries out pro-American policy or rather appeases Teheran, what is observed recently. This could put Riyadh and other American allies in even worse situation than before 2003 when although Iraq and Iran were Riyadh's enemies, they had difficult relations between each other. Therefore traditional America's allies might get forced to seek new partners. On the other hand, new emerging powers like China and, India which will depend more and more on Middle East's resources, should be more involved in stability issues of the region, taking over American influence.

Although it is still it is not clear whether Washington is determined enough to directly influence the global energy market thanks to exporting its hydrocarbons (Lugar 2012), authors believe that American foreign policy preference will maintain its current position on the energy market. Thanks to the predominant position of the US on the international scene and the vast choice of efficient instruments of foreign policy, Washington does not need to use energy in order to increase its political influence. The experience of past decades shows that Americans are even more eager to limit production of its strategic resources in case the situation in global energy markets deteriorates. ${ }^{8}$ That leads to conclusions that although America, due to its technology leadership (e.g. shale gas), may present an offensive approach supporting new developments on global energy markets (both through bilateral and multilateral diplomacy), it will rather present a conservative strategy without undertaking an expansive policy on foreign markets in comparison to previous years. Thus, the recent developments on the global energy markets will have probably positive but moderate implications for US. However, taking into account the changing Washington's energy interests, it will represent one of many factors for a slow consolidation of US global involvement (Brzeziński 2012).

As regard to China, if anyone doubts whether it will becomes a leading regional or global power should look up at its global energy developments implications. China, which has not been traditionally very involved in energy diplomacy thanks to

\footnotetext{
${ }^{7}$ Nowadays, the presence of American troops is even more crucial for Saudi Arabia. After the attacks of the 11th of September 2001 and Riyadh's support for American war against terrorism, the ambience of Saudi Arabia is more hostile towards the royal family. There are not only traditional opponents like Iran, Syria, but also new governments that have emerged after the Arab Spring, in major part with Shiites influence.

${ }^{8}$ Nowadays there is a discussion in the United States regarding possible use of growing production of shale gas and oil. President Obama's administration is skeptical about a perspective of exporting its strategic resources focusing more on internal energy security. Politicians close to the Republicans, on the other hand, suggest to use energy as a new offensive component of foreign policy, including cooperation in this area with NATO countries.
} 
its rapid economic growth, in few years might become not only the biggest energy world consumer, but also, with the scale of domestic market, the most important energy trend launcher as well (Qinhua 2007). ${ }^{9}$

The changes on energy markets will have serious geopolitical implications for China. Sharp increases in energy requirements means that development of domestic energy production and implementing efficiency policies will be not enough for Chinese demand. Due to the lack of domestic supply and increasing dependence on imported energy, the highest preference in Chinese energy policy will be enhancement of energy security. The imperative for China energy strategy will be therefore to "pluralize" gas and oil sources and increase the security of energy transportation. Counting on external supplies can make China more vulnerable for new types of problems related to war against piracy, control of transit corridors. That means that Beijing will be forced to conduct more expansive foreign policy both in regard to bilateral and multilateral relations (e.g. a stronger involvement in activity of the Regional Piracy Center in Kuala Lumpur) to provide stable supplies from abroad.

The first step has been already made through strengthening relations with Central Asian energy suppliers - one of China's core areas of international energy cooperation. This pattern was characterized by dedicating great efforts in building gas and oil pipelines between China and Kazakhstan, Turkmenistan and active participation in the gas and oil exploitation of other countries, such as Uzbekistan (Xuetang 2006). There have been also long talks with Russia regarding building new gas pipeline (the new oil pipeline is active since 2010) but considering the consistent lack of trust between the two countries and a popularization of LNG, it seems that the western direction is not going to be the only alternative for Chinese energy policy. To ensure that its international energy interests are realized, China must undertake steps to resolutely develop energy relationships with different actors far beyond traditional zone of Beijing influence. In this regard, in the coming years, Chinese will probably increase activities in Africa or in Greenland.

The recent WEO (2012) report says that the region MENA will become a crucial for oil and gas import in the future. WEO (2012) predicts that by 2035 China will be the biggest importer of Middle East oil. Therefore China depending on Iranian oil could continue to back Teheran nuclear program in the short term. But in the long term, especially if Washington's decreases its interests as a consequence of gaining energy dependency, Beijing will be forced to get more involved politically and take bigger responsibility for the whole region. That could mean more balanced approach and the necessity of strengthening relations with traditional American partners like Saudi Arabia and Iraq. ${ }^{10}$ The possibility of a military presence of Chinese troops in order to protect its strategic suppliers, control of transit corridors and to fight against piracy should not be excluded.

Another important Chinese foreign policy factor emerging from the new developments on global energy markets is a growing number of big consumers

\footnotetext{
91993 was the crucial year for China when it turned from an exporter of crude oil into a pure importer.

${ }^{10}$ However, Riyadh and Beijing relationship seems difficult taking into account the Chinese support for Teheran.
} 
competing for oil and gas, especially India and Japan, which will be forced to find a replacement for nuclear power after the country has decided to gradually move away from this source of energy consequently the Fukushima disaster. China and India, rather than conducting strong competition, have started to cooperate in this field, exploiting oil in Kazakhstan and jointly entering into the Sudan oil exploitation project, thus becoming business partners. They have also begun to work together in Iran. In the future, China and India should work hand in hand, taking part in international energy exploration and distribution, diversifying risks what can bring both countries closer politically. The Japanese case is far different because of the difficult political relations conditioned by past affairs and the fact that Tokyo has been traditionally an ally of Washington. Moreover, both countries are in disputes over energy-rich areas such as the South China Sea (Caldwell Harris 2001). With increasing energy demand in the two countries, this dispute could explode with a new power, leading to a serious regional crisis.

To sum up, the new trends in the global energy markets and the increasing demand for energy will force Beijing to a stronger commitment to new regions of the world and running almost global stabilization policies to strategic locations such as the Middle East. Thus, China will slowly take the role of the US as a protector of stability for some countries. At the same time Beijing is likely to be presented in a more assertive stance of unresolved disputes in energy-rich areas. ${ }^{11}$

Qatar is the largest LNG exporter and one of the largest gas producers in the world. Thanks to relying on LNG infrastructure ${ }^{12}$ Qatar has a greater flexibility in where it sends its natural gas than countries bounded by pipelines. What is the most important about this tiny country is its capacity in converting energy resources into political power. The country, which for many years used to be perceived as a "smaller brother" of Saudi Arabia, thanks to energy sector modernization in 1990s and sophisticated tools of foreign policy has undergone a remarkable transformation to emerge as a regional key player, also with a global influence (Qatar hosts of the Gas Exporting Country Forum). The Arab Spring showed it fully when Doha was giving military support to the opposition of Colonel Muammar Gaddafi in Libya as well as backing key players in another countries (Steinberg 2012). However the biggest weapons of Qatar's foreign policy with the global impact is the TV station Al Jazeera-soft power tool which has revealed itself to the whole world as a political instrument of the Qatari leadership. The success of this TV would not be possible without the gas export profits (Hroub 2011).

The current WEO (2012) forecast seems to be rather moderate-positive for Doha. Both the growing demand of gas and LNG export development—where Qatar has a leading role, should only consolidate its strong position at the market. There is also no big risk from competitors. The supply from new LNG exporting countries (e.g. Mozambique) should be rather directed towards Asia. Therefore, Doha should maintain its contracts, especially as it owns interests in LNG import terminals in

\footnotetext{
${ }^{11}$ According to US National Intelligence Council: "China and India's perceived need to secure access to energy supplies will propel these countries to become more global rather than just regional powers, while Europe and Russia's co-dependency is likely to be strengthened."

12 Qatar has two LNG complexes-Qatargas and Ras Laffan but also one of the largest LNG tanker fleets.
} 
Table 1 The comparative overview of case studies

\begin{tabular}{lllcl}
\hline & Russia & United States & China & Qatar \\
\hline $\begin{array}{l}\text { Implications for } \\
\text { geopolitical } \\
\text { position }\end{array}$ & Strong and negative & Moderate and positive & $\begin{array}{c}\text { Strong and } \\
\text { negative }\end{array}$ & Positive \\
$\begin{array}{c}\text { Foreign policy } \\
\text { preference }\end{array}$ & $\begin{array}{c}\text { Maintaining its current } \\
\text { position on the energy } \\
\text { market }\end{array}$ & $\begin{array}{c}\text { Maintaining its current } \\
\text { position on the energy } \\
\text { market }\end{array}$ & $\begin{array}{c}\text { Energy } \\
\text { security }\end{array}$ & $\begin{array}{c}\text { Growing } \\
\text { political } \\
\text { power }\end{array}$ \\
$\begin{array}{l}\text { Strategy } \\
\text { Expansive-defensive }\end{array}$ & $\begin{array}{c}\text { Conservative-offensive } \\
\text { Expansive- } \\
\text { offensive }\end{array}$ & $\begin{array}{c}\text { Expansive- } \\
\text { offensive }\end{array}$ \\
\hline
\end{tabular}

Source: Own elaboration

Europe and the United States. Moreover, changes in Qatar's environment caused by the new energy developments do not seem to have such a serious geopolitical impact like in the Saudi Arabia case. Even lower Washington's interest of this region caused by US energy independence (Qatar is currently hosting an important US military Central Command facilities that support ongoing operations in MENA, Iraq, and Afghanistan) should not put Doha in a serious risk. It is because Qatar's foreign policy is driven by a strong pragmatism and sympathy for Islamists. ${ }^{13}$ On the one hand, the basic principles of Qatar's foreign policy played a major role in its policies towards countries of Arab Spring (that's why Qatar was positioned as ally of the West in the democratic changes in Arab Spring). On the other hand, Qatar's leaders provided targeted support to Islamists and Salafists. Qatar is currently ready to speak not only with the main actor of Arab Spring-the Muslim Brotherhood but also with al-Qaeda. It is easier for Doha to speak to extremists than for Riyadh. The Qatari monarchy has little in common with fallen republican regimes in the Arab world (Muslim Brotherhood and Salafists are closer to their interpretation of Wahhabism) whereas Saudi Arabia relations with this organization deteriorated sharply after WTC giving a strong support to US (Steinberg 2012).

Summarizing, the new energy trends do neither pose serious direct risks for geopolitical position of Qatar nor for its environment. That means that Qatar can continue its policy based on empowering of state thanks to a stable income from energy resources and using its sophisticated soft power-Al Jazeera.

The comparative overview of the geopolitical implications of the new developments on global energy markets provided (Table 1), explains how Russia-which up to now was fairly building its geopolitical position on gas resources - and China_characterised by negative perspectives regarding increasing energy import dependency - will be probably negatively affected by new developments on energy markets.

Moscow and Beijing will be forced to seek new partners in non traditional zone of their interests or undergo an expansive foreign policy on international arena to

\footnotetext{
13 Qatar hosts the Taliban and Hamas regional offices, as well as a host of international organizationsGeorgetown University, the British Royal United Services Institute for Defence and Security Studiescreating a space where the west rubs shoulders with the Islamic world. Until 2009 Qatar even hosted an Israeli trade centre, which has to be closed after the Israeli incursion into Gaza.
} 
protect their energy security or, at least, to maintain the current position on the energy market. To this end, in order to postpone those changes, Russia will probably adopt a defensive strategy; while China, on the other hand, will implement a more offensive strategy, as it is interested in new technologies to meet its own energy demand.

At the same time, it is likely that US and Qatar will take advantage of the changes occurring on energy markets. The leading role in sectors with growing trends like LNG and shale gas will predispose those countries to more offensive attitude towards the new developments. However, with the experience of past decades showing that the US are more eager to limit production of their strategic resources in case the situation in global energy markets deteriorates, Washington will rather not be inclined towards using energy as a political tool and will prefer to consolidate its energy security by maintaining its leading position on the shale gas market. To this end, US might adopt a rather conservative strategy based on decreasing its involvement in the Middle East. Analysing the recent Qatar's involvement in the Arab Spring and its capacity of converting its energetic potential into political power, we might expect this country to continue an expansive foreign policy to be aimed at increasing its influence in the region.

\section{Conclusions}

This article attempted to analyse possible implications related to the new developments occurring on global energy markets, taking into account main energy actors and their foreign policy preferences and strategies. In doing this, it was assumed that changes on the global energy markets, such as bigger competition and flexibility of transport, will lead to their progressive liberalization, even if they will not fairly de-politicize the energy policy that, in the end, will still be an important factor of international relations. However, in the future, using energy directly as a political negative tool might be more and more difficult. This means that the winners of the global strategic resources game will be those states able to use more sophisticated foreign policy tools and which have an open approach to new developments (US, Qatar); while, those countries that will keep on using energy as direct pressure (Russia) for empowering its geopolitical positions might find themselves in troubles.

The presented evidence suggests also that changing energy outlook may redefine global geopolitical balances and disrupt the existing patterns. Growing dependence on Middle East oil imports will affect Asia, especially China for decades to come and create new imperatives to strengthen relationships with suppliers. It means that in the future Beijing, one of the biggest energy consumer, will be probably driven to take over the American role and responsibilities. As a result, China will have to conduct a similar foreign policy like the current American one, protecting its strategic suppliers and being more involved in transport security. Furthermore, Qatar might be taking Russian role as it performed greater capacity in converting energetic resources into political power. Traditional producer countries like Russia, on the other hand, apart from conducting foreign policy having as main goal the 
prevention of those changes, might seek new strengths for their geopolitical positions, such as controlling transit routes.

While the findings presented in this paper account for the geopolitical implications for four major energy actors, further research regarding political risks is needed to confront and develop the preliminary conclusions. In doing this, it would be especially interesting to examine and explain the water issue and new transit routes in the wider energy context.

Open Access This article is distributed under the terms of the Creative Commons Attribution License which permits any use, distribution, and reproduction in any medium, provided the original author(s) and the source are credited.

\section{References}

Blank JS (2011) Russia in the Arctic. Strategic Studies Institute, US Army War College

Brzeziński Z (2012) After America: how does the world look in an age of US decline? Dangerously unstable. Foreign Policy, JAN/FEB 2012

Burgess J (2012) Gazprom funds anti-fracking campaigns in Europe? Oilprice.com. http://oilprice. com/Latest-Energy-News/World-News/Gazprom-Funds-Anti-Fracking-Campaigns-in-Europe.html

Caldwell Harris M (2001) The globalization of energy markets. In: Kugler RL, Frost EL (eds) The global century globalization and national security. National Defense University Press, pp 271-283

Carr E (2001) The twenty years' crisis, 1919-1939. Perennial, New York

Donnelly J (2008) The ethics of realism. In: Reus Smit C, Snidal D (eds) The Oxford handbook of international relations. Oxford University Press, Oxford, pp 150-171

ExxonMobil (2012) The outlook for energy: a view to 2040, Texas-Irving

Fandy M (1997) US oil policy in the Middle East. Foreign policy in focus

Forbes, the world's biggest oil companies (2012)

Frieden J (1999) Actors and preferences in international relations. In: David L, Powell R (eds) Strategic choice and international relations. Princeton University Press, Princeton, pp 39-76

Giordano A (2009) Relazioni UE-Russia, energia e politica internazionale. Europa-quarterly of European Affairs, n. 2, Rubbettino Editore, Soveria Mannelli, pp 61-75

Hroub K (2011) How Al-Jazeera's Arab spring advanced Qatar's foreign policies. Europe's World Autumn 2011

Hryniewiecki R, Boronska K (2010) Factors affecting the world oil market. In: Noga M, Stawicka M (eds) Globalization and competitiveness in world economy. CeDeWu, Warsaw, pp 82-91

IEO (2012) Iraq energy outlook special report, Paris

International Energy Agency (2011) Are we entering in a golden age of gas? Paris

Kaplan RD (2012) The geopolitics of Shale. Stratfor, Washington, DC

Kardaś S, Paszyc E (2012) At any price: Russia is embarking on the construction of South Stream. Centre For Eastern Studies, Warsaw

Konończuk W (2012) Russia's best ally. The situation of the Russian oil sector and forecast for its future, vol 39. Centre for Eastern Studies, Warsaw

Lake D, Powell R (1999) Strategic choice and international relations. Princeton University Press, pp 3-39

Levy JS (1997) Prospect theory, rational choice, and international relations. Int Stud Quart 41:87-112

Lugar R (2012) Liquefied natural gas (LNG) for NATO. http://thehill.com/images/stories/news/ 2012/12_december/sfrc_report.pdf

Mearsheimer J (2001) The tragedy of great power politics. W.W. Norton \& Company, New York

Qinhua X (2007) China's energy diplomacy and its implications for Global Energy Security. FES Briefing Paper 13

Quercia P (2012) Sistema energetico e sistema internazionale. In: Villafranca A, Quercia P (ed) La politica estera dell'energia: L'Italia, la sicurezza energetica e gli interessi internazionali, research project ISPI-Farefuturo, Milano, pp 17-66

Ratner M, Nerurkar N (2011) Middle East and North Africa unrest: implications for oil and natural gas markets. Congressional Research Service Report for Congress 
Statoil (2012) Energy perspectives: long-term macro and market outlook. http://www.statoil.com/ en/NewsAndMedia/News/Downloads/Energy\%20Perspectives\%202012.pdf

Steinberg G (2012) Qatar and the Arab Spring, support for Islamist and new Anit-Syrian Policy, SWP Comments 2012/C 07. German Institute for International and Security Affairs, Berlin

WEO (2012) World energy outlook 2012, Paris

Xuetang G (2006) The energy security in Central Eurasia: the geopolitical implications to China's energy strategy. The China and Eurasia Forum Quarterly, vol 4, no 4 